\title{
The Impact Of Leadership Behavior On The Business Growth Through The Organizational Innovation And Managerial Practices
}

\author{
Muhammad Rafiq \\ Assistant Professor, Superior University, Lahore, Pakistan
}

Muhammad Haris

Project Manager, evening program, Superior University, Lahore, Pakistan

Malik Javied Anwar

Senior Lecturer, Superior University, Lahore, Pakistan

\author{
Kashif Bilal Majeed \\ Superior University, Lahore, Pakistan
}

\begin{abstract}
The main objective of this empirical study is to determine the affect of leadership behavior with the organizational innovative techniques and managerial practices on the businesses' growth in Pakistan particularly in textile sector. Firstly, the study discusses the relationship between leadership behavior and organizational innovation, between organizational behavior and managerial practices. Furthermore, this relationship is also measured between organizational innovation and business growth and between managerial practices and business growth. Secondly, the study investigates that these relationship are strongly reinforced in the firm with the support of theoretical evidences made but not determined theoretically in the prior literature. Managerial practices take place in textile community for interaction in which organizational cognition is developed and expanded dynamically between the cognitive and behavioral changes. Organizations with greater organizational acquisition and practices create a learning network that will become easier to learn that what they use to learn and to initiate, enabling the firm to preserve its effective and competitive aversion as a textile technological center. Nomothetic research method is applied to test the hypothesis, developed for this study. The research examined a sample of one hundred ten textile firms with sample unit of senior managers, executives, administrative and other-level managers. A research model is formulated for the study and hypotheses are tested with the use of structural equation model. This study purposes that the leaders of firms initiate a transformational role, which facilitate organizational innovation and managerial performances and consequently enhance the business growth especially in textile firms.
\end{abstract}

Keywords: Leadership behavior, Organizational innovation, Managerial performance, Business growth.

\section{INTRODUCTION}

Leadership has been considered as a significant factor that has much influence on innovation and organizational performance. Therefore, organizational leadership and innovation techniques are the crucial factors for achieving the strategic competitiveness in present day (Ireland and Hitt, 1999). Strategic leaders have recognized for their vital role in allocating opportunities and decisions making that affect on innovation management, managerial activities and the firm performances (Finkelstien and Hambrick, 1996). Transformational 
leadership, one type of leadership, is described as the method of leadership that heightens the consciousness of joint interest among all the members of organizations and helps to attain their collective goals. As contrary to this, traditional leadership focuses on enhancing the individual interest of firm's leaders and their members and achieving the satisfaction of authorized obligations (Bass and Avolio, 2000). Leaders use both transformational and transactional behavior to different degrees of firm (Bass 1999).

Various transformational leadership theories emphasize on values, emotions and the importance of leadership behavior to encourage the employees' creativity. Employees are the main resource in the firm, Transformational leaders takes responsibility for, to promote the professional development of the employees (Bass and Avolio, 2000; Garcia Morales, 2008). The leadership behavior creates emotional links with the fellow members and acts to empire the higher values. Such, leadership that has responsibility to transmit the role of creating a shared mission and having a sense of direction and purpose in the followers is known as transformational leadership (Bass, 1999). The leadership becomes the motor for innovative culture and knowledge oriented for, to seek the best organizational performance (Bass, 1999; Bass and Avolio, 2000). Transformational leaders have charisma, create inspiration and promote intellectual stimulation (Bass, 1999; Bass and Avolio, 2000). Charisma generates the faith, pride and respect that encourage their members, their leaders and their organizations as whole to grow. Transformational leaders provide inspiration and motivation to their followers through communication of high manufacturing expectations. Such leaders also promote the employees' intellectual stimulation by promoting their knowledge, intelligence and learning to become innovative in their problem solving techniques (Bass and Avolio, 2000).

Various studies analyzed the affect of transformational leadership on business performance through the different intermediate constructs such as knowledge management (Gowen, 2009), entrepreneurship and entrepreneurship education (Rafiq, et.al. 2015; Garcia Morales, 2006), organization culture (Ogbonna and Harris, 2000), flexible behavior (Rodriguez ponce, 2007)human resources management to enhance human- capital (Zhu,Chew and Spangler, 2005) top management teams (Colbert, Kristof, Bradley and Barrick, 2008) and absorptive capacity (Garcia, Jimenez and Gutierrez, 2008).

The Literature proposes different concepts of innovation. This study uses the formulated definition of innovation introduced by the Product Development and Management Association (PDMA) that analysis innovation as; a new idea, method, technique or device. The act of generating a new process or product that can ensure the growth of organization is known as innovation. The act includes invention and the work required as a concept or idea to bring into final form (Bellivean, 2002). Although researches prescribe firm innovation as a main source of improving organizational performance, many firms do not develop innovation properly (Zollo and Winter, 2002). The study emphasizes the great importance on managerial practices and innovation for a firm's survival and effective performance (Van de Ven, 1993). Managerial practices and organizational learning are the major components to improve the organizational performances and to strengthen the competitive advantage. The new knowledge, derived from organizational learning and managerial performance enable the firm's competencies to remain dynamic and to improve in performances. Organizational learning is positive associated idea that contains different forms of performances (Argyris and Schon, 1996; Inkpen and crossan; 1995; Ireland et al, 2001). Various authors describe that innovation is the foundation to improve firm's performance and moreover, innovation plays an important role in order to improve managerial performance (Argyris and Schon, 1996; Damanpur, 1991; Hurley and Hult, 1998). 
To summarize, this study describes the influences of leadership on the organizational innovation and managerial performances and give importance to provide empirical results that demonstrate these relationship. The model also claims to prove the positive and significant relation between organizational practices and innovation and demonstrates these dynamic capabilities and performances. To achieve the objective of the article, the section based on a series of hypothesis that influences of transformational leadership on organizational innovation and managerial practices with business growth and organizational performances. The method section specifies the data and the technique that used to analyze the hypothesis empirically in the textile firms. The results section describes the findings among the variables. Finally, the section on conclusion discusses the results and points out some limitations of this study.

\section{LITERATURE REVIEW}

The strategic literature emphases on leadership style as an important influence on organizational innovation (McDonough, 2000). Generally, there is broad consensus that a participative and collaborative firm's leadership style is to encourage organizational innovation in the manufacturing sector (Kanter, 1983) than transactional leadership style (Manz, 1989). It is important to show the role of manager's perceptions in their organization that strongly influences to promote this style of leadership behavior in manufacturing organization. Transformational leaders promote organizational innovation within the firm content-in other words, Leadership is the tendency to innovate in the organization. Transformational leaders use creational motivation and intellectual improvement, which are important for organizational innovation (Elkins and Keller, 2003). Such leaders promote new ideas in their organizations, their leadership behavior are proposed to act as "Creativity enhancing forces", "Serves as a reward", "enhances exploratory thinking" and "provides encouragement into the idea generating process" (Sosik, Khai, and Avolio, 1998). Leaders develop their followers' self-determination, self-raising and self-esteem (Bass, 1990). These types of leaders motivate their followers by their energy, enhancing employees willingness to act beyond expectations, and stimulates them to apply innovative approaches in their work. This result motivation and self-confidence in the members to improve organizational innovation and business growth (Mumford, Scott, Gaddis and Strange, 2002).

Transformational leadership constructs team work and provides members a vision, energy and support for innovative processes and organizational performances (Bass, 1999; McDonough, 2000). This style set aside for organizations to learn through experiments, investigations and communications (Menguc, Avh and Shih, 2007; Slater and Narver, 1995). More specifically, the transformational leadership fuels the organizational performance by enhancing intellectual stimulation, rational motivation and self-esteem among the organization members (Coad and bervy, 1998). Transformational leadership creates greater consciousness and mission of the organization and promotes a shared vision, and establishing of a team work. This style of leadership allows the leader to learn, commit and become its driving force and also provide the desirable techniques to overcome internal and external difficulties to establish managerial learning within the organization (Wick and Leon, 1995). Several features of leadership are related to the organizational innovation (Gumusluoglu and Ilsev, 2009; Lian Shao, 2006). Transformational leaders have a passive vision; they pay optimum level of attention to promote effective communication (Adair, 1990) and fostering an environment for innovative team (Tushman and Nadler, 1986). All the features of leadership enable a better knowledge of strong relationships between the transformational leadership and there elements certainly influencing organizational innovation (Kanter, 1983). 
Finally, transformational leaders have provided inspiration, to promoting intellectual values of members. Thus Leadership affecting on innovation indirectly with the communication process (Garcia-Movales, 2004) and create the style of organizational knowledge (Nonaka and Takeuchi, 1995). Further, transformational leadership has an influence on the innovation based on both factors and co-relation between them (Communication and organizational performance) (Schein, 1993; Senge, 1990).

The literatures influence on the importance of organizational innovation for a company's survival and is considered essential for effective performance (Argyris and Schon, 1996; Inkpen and Crossan, 1995). Various marketing theories describe that organizations attain a high market share concentrating on innovation speed, which generates high income and profitability. Strategic theories emphases that the firms adopted organizational innovation method are able to make isolation mechanisms. Similarly, the resources and capabilities theory maintains that resources and technologies required making organizational innovation externally and allowing firms to attain their competitive advantages and receive higher organizational performance (Irwin, Hoffman and Lamont, 1998; Lengnick-Hall, 1992). Thus, there are many important factors that influence on the successful management portfolio of product innovation. These factors of product innovation are;
I. Strategy and leadership behavior
II. Firm planning and selection
III. Organizational structure and performance
IV. Effective communication and collaboration.

\section{Strategy and leadership behavior}

Leadership behavior and strategy have been recognized as the first important factor to enable the effective innovation management for the product. The product strategy importance is well documented in different literature (Englund and Graham, 1999; Jones, 1997; Bookhart, 1996). A product strategy defines the main objectives of product innovation in association to the organization's strategy. It specifies market targets to formalize the essential structures for implementation. A product strategy also focuses and integrates the team effort. Every worker in the project team have an input in product innovations and transformational leaders have an effective impact on the product innovation initiatives (Cooper, 1999; Cooper and Kleinschmidt, 1996). Leaders engage innovative practice at all organizational levels and create effective communication in product innovation methods (Englund and Graham, 1999).

\section{Firm planning and selection}

An intellectual planned product innovation is an important factor for the success. Cooper \& Kleinnsehmidt (1996) emphasis on the significant pre-define development activities to solve the problems in advance and facilitate the new technologies. It is essential for effective planning and selecting projects, which are focused on customers demand and link to the product strategy and objectives (De Brentani, 2001; Shepherd and Ahmed, 2000). Therefore, a clear understanding of consumer needs is core to product innovation plans and all the product operations driven by these users needs. Calantone, Benedetlo and Schmidt (1999), explore 'the screening of new product ideas is perhaps the most critical new products development activity, yet it often is performed poorly'. The screaming process coordinates to eliminate the extensive use of resources and focus on the critical efforts. In this view, firm success depends on the best potential among different projects (Cooper, 1999).

\section{Organizational structure and performance}

An organizational structure and managerial performance have been recognized as a main enabler for the effective innovation management. Two different theories of organizational 
structure are mechanistic (technique) and organic (Cumming, 1999), the mechanistic approach reinforce the previous behaviors while the organic structure promotes organizational learning and generating business knowledge (Cumming, 1999; Bacts, 1998; Davenport and Prusak, 1998). Knowledge sharing and knowledge transfer depends on the member personal network and willingness (Jones and Jorden, 1998; Ruggles, 1998). Organizations are beginning to organize the reporting lines and firm structure not around the functional department. Team work are becoming the main organizational component for new economy (Shephered and Ahmed, 2000; Kayworth and Leindner, 2000). Similarly, Employees motivation and rewards system are the key elements in maintaining the interests of employees (Bukowitz and Petrash, 1997). Furthermore, there are various reports for practical incentive mechanisms which linked with measuring and rewarding the new idea generation and knowledge sharing. Many firms still use traditional performance measures which are inappropriate indicators of organizational success.

\section{Effective communication and collaboration}

The final important factor for the product innovation management is effective communication and collaboration. The product innovation is the process of knowledge intensive (Davenport and Prusak, 1998; Drucker 1993). Firm communication described as an informational transformational process where the passive information is gathered and then transferred in an innovation way. Therefore, communication is the vital element for product innovation many researchers highlight that external communication is the main element for the successful product innovation (Mendelson and Pillai, 1999; Poulton and Barclay, 1998). Customer commitment has been proven to enhance the effectiveness of firms' project (Shepherd and Ahmed, 2000; Leonard and Sensiper, 1998). Internal communication is also the important element for product innovation success. Many researchers emphases on the effect of communication and co-operation among the employees that strongly relate to the project success (Maltz, 2000; Liberatone and Stylianox, 1995).

Different theories explain that organizational innovation is necessary for the better organizational performances. According to various marketing theories organizations that concentrate on the innovation attain the major share of market that produces high level of income and profitability (Irwin, Hoffman and Lamont, 1998). Thus, a passive relation exists between the organizational innovation and firm performance (Zahra and George, 2002). The organizational innovation literate has various empirical studies which supporting this relationship. Organizations that have greater innovation will attain the better response from the business environment, obtaining more capabilities that needed to enhance organizational performance (Calantone, Cavusgiliand Zhao, 2002). Organizational innovation as a main dimension of intrapreneurship has a significant influence on organizational performance (Hudge and Morgan, 2007).

Leadership is an organizational move toward becoming transformational leadership that inspires the workers to participate with enthusiasm in group efforts and analyze beyond their personal interest, reorganizing the training of employees and construction of teams to promote business performance (Bass, 1991). The main internal reasons of organization's failure is the leaders inability that suppose to the transformational role needed for stimulating organizational performances and to create potential ability between transformational leadership and firm performance. High performances in the firms are stimulated by exploring positive organizational climate. Leaders invest their time and resources to organize teams; they have required competencies to execute the strategic changes in organization (Nadler and Tushman, 1990). 
Previous studies have asserted co-relation between organizational leadership and learning, showing their affect on firm business growth (Bierly, Vessler and Christensen, 2000). Traditional leadership is mainly individualistic and less necessary for organizational learning and team making. As contrary to this transformational leadership construct team work and provides support for processes change that improve business growth through better and effective leadership (Bass, 1999; McDonough, 2000). More specifically, Transformational leadership is fostered by organizational learning and business practices by promoting intellectual stimulation, motivation and self-esteem among the organizational members (Coad and Berry, 1998). Organizational learning encourages shared models and favor transformational leadership and new technologies that enhance business performance (Senge, Roberts, Ross, Smith and Kleiner 1994).

Figure1: Frame work

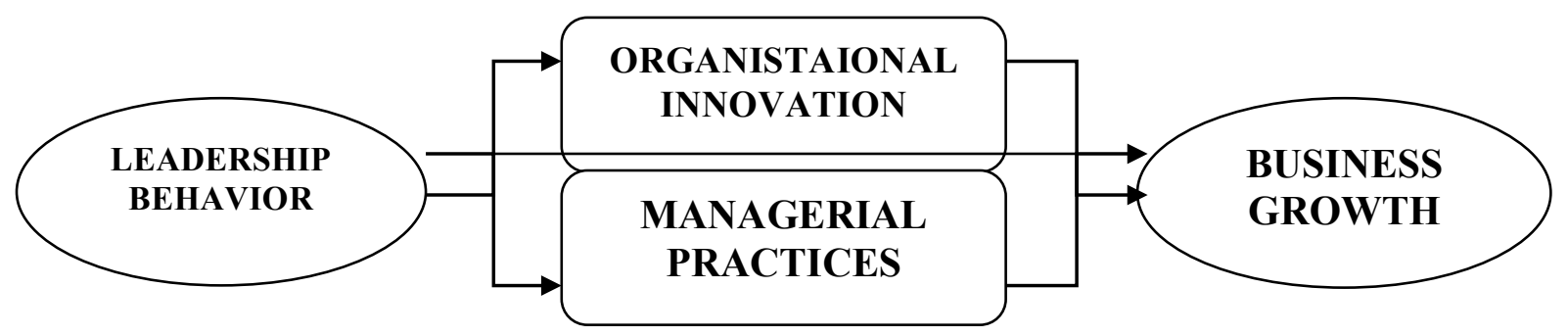

\section{HYPOTHESES}

H1: A positive association exists between leadership behavior and organizational innovation.

H2: A positive association exists between leadership behavior and managerial practices.

H3: A positive association exists between organizational innovation and business growth.

H4: A positive association exists between managerial practices and business growth.

H5: A positive association exists between leadership behavior and business growth.

\section{METHODOLOGY}

This study believes on positivism paradigm, which believes on objective reality of nature. This research uses deductive approach to test the hypothesis. The first step in the empirical study is the selection of population which to be analyzed. The population consists of the important textile organizations in Lahore, Pakistan. The sample was selected randomly from the one hundred sixty companies that had the required number of employees. This study uses the sample unit of top management, administrative and other-level managers of the organization. One hundred ten companies agreed to participate in the study. Three hundred questionnaires were distributed among the sample group, out of which 258 (86\%) were returned and have been completed. SPSS 20 is used in this study to analyze the data collected from textile sector of Lahore, Pakistan. Descriptive statistics, factor analysis and reliability analysis (Cronbach's alpha) are used to test the factors validity and reliability of questionnaire measures. Similarly, correlation and regression analysis are process to find the relationship between the variables.

\section{Analysis and Results}

This section presents the analysis of data which firstly discusses the demographic profiles of the different respondents and explain the descriptive summary that include the mean and standard deviations for all selected variables. It is followed by estimated reliability results and factors validity of measurements of constructs. Secondly, this section presents the results of regression analysis and hypotheses tests to examine the hypothesized relationships in the model. 


\section{Descriptive statistics}

\section{Demographic profile of respondents}

A total of 300 questionnaires were distributed to top management, administration and other core staff of textile firm in Lahore out of which 258 questionnaires were return which shows a reasonable response rate of $86 \%$. The demographic profile of respondent is given in table 1 . This table contains information on the basis of education, job position, legal status, sector and staff.

Table: 1 Demographic profile of respondents

\begin{tabular}{|l|c|c|}
\hline Respondent demographics & Frequency (N) & Frequency (\%) \\
\hline EDUCATION: (N = 258) & 17 & 6.6 \\
Primary & 60 & 23.3 \\
Secondary & 71 & 27.5 \\
Tertiary & 77 & 29.8 \\
MSc, M.A & 33 & 12.8 \\
Professional studies & & \\
\hline Job Position: (N = 258) & 52 & 20.2 \\
Top Management & 69 & 26.7 \\
Middle Management & 47 & 18.7 \\
Core Staff & 42 & 16.8 \\
Administrative Personnel & 48 & 18.6 \\
Other & & 1.6 \\
\hline Legal Status: (N = 258) & 4 & 58.9 \\
Public & 152 & 39.5 \\
Private & 102 & \\
Other & & 49.3 \\
Type of Sector: (N 258) & 127 & 2.3 \\
Manufacturing & 6 & 1.9 \\
Services & 5 & 3.1 \\
Researches & 8 & 43.4 \\
Consulting & 112 & 1.2 \\
Other & & 9.3 \\
\hline Staff: (N = 258) & 3 & 38.3 \\
Up to 9 & 24 & \\
10-49 & 99 & \\
50-249 & & \\
More than 250 & & \\
& & \\
\hline
\end{tabular}

Table 1 shows that out of 258 respondent, 17(6.6\%) are primary education, 60(23.3\%) are secondary education, $71(27.5 \%)$ are tertiary education, $77(29.5 \%)$ are masters level and $33(12.8 \%)$ are Professional Studies; the entire respondent provide information regarding their education. Of the 258 respondents, $52(20.2 \%)$ are top management, $69(26.7 \%)$ are middle management, $47(18.7 \%)$ are core staff, 42(16.3\%) are administration personnel and 48(18.6\%) are other employee of the firm; all respondents provide information there job position. Out of 258 respondents, $4(1.6 \%)$ are public sector, $152(58.9 \%)$ are private sector and $102(39.5 \%)$ are other sector, the entire respondent provide information regarding their legal status. This shows the most of the respondents belongs to private sector.Out of 258 respondents, $127(49.2 \%)$ are manufacturing sector, $6(2.3 \%)$ are services sector, $5(1.9 \%)$ are research sector, $8(3.1 \%)$ are consulting sector and $112(43.4 \%)$ are other related sector; all the respondents provide information regarding their type of business sector. Out of 258 
respondents, 3(1.2\%) are below the $9,24(9.3 \%)$ are from 10 to 49 members, 132(51.2\%) are 50 to 249 members and $99(38.5 \%)$ are 250 to above members; all the respondents provide information regarding number of staff in the companies. The above discussion shows that the selected samples may be considered to a good representative of the population.

\section{Reliability Analysis}

In the table 2, shows the estimated values of Cronbach's co-efficient alpha that examine the reliability and consistency level of measures. In this sample, the values of Cronbach's alpha vary from $(0.828$ to 0.872$)$.this declare that each multi-item construct high level of reliability. Leadership behavior (alpha $=0.828$ ), Organizational behavior (alpha $=0.833$ ), Managerial performances (alpha $=0.872$ ) and Business growth (0.858). The Cronbach's alpha value implies that all the factors are internally consistent. In short, the reliability analysis gives the same construct among the higher Cronbach's value of a construct.

Table: 2 Reliability of measurement

\begin{tabular}{|l|c|c|c|}
\hline Constructs & Valid N & $\begin{array}{c}\text { Number of } \\
\text { Items }\end{array}$ & $\begin{array}{c}\text { Cronbach's } \\
\text { alpha }\end{array}$ \\
\hline Leadership Behavior & 258 & 8 & 0.828 \\
\hline Organizational Innovation & 255 & 10 & 0.833 \\
\hline Managerial Practices & 258 & 7 & 0.872 \\
\hline Business Growth & 258 & 5 & 0.858 \\
\hline
\end{tabular}

\section{Factor analysis}

Factor analysis conducted while using PCA techniques with varimax rotation method to confirm the validity of different construct. These different results are given in the table 3 and table 4 respectively. To check the data adequacy, the study employed the KMO techniques of sample adequacy test and Bartlett's test of sphericity. This sampling shows how strength connection between the variables as a well as sphericity refers to the orthogonally of different components.

\section{KMO measure of sampling adequacy test and Bartlett's test of sphericity}

The KMO techniques of sampling indicate the suitability to employ the factor analysis. The KMO values lies between 0 and 1 . The value of " 0 " indicates the high dispersion in correlation patterns. The value of " 1 " indicates the correlation patterns are relatively compact. Then factor analysis applications can become in-appropriate or appropriate. The KMO value better value lies between 0.6 to 1 and consider poor if below to 0.5 . The results mentioned in table --- are all consider being better because values lies between 0.6 to 1 . The Bartlett's test shows the significance of relationship between the different construct. Generally, the p-value $<0.05$ refers to significant relationship among variables.

Table: 3 KMO and Bartlett's test

\begin{tabular}{|l|c|l|l|c|}
\hline Constructs & $\begin{array}{l}\text { No. of } \\
\text { items }\end{array}$ & $\begin{array}{l}\text { KMO } \\
\text { Measure of } \\
\text { sample } \\
\text { adequacy }\end{array}$ & $\begin{array}{l}\text { Bartlett's Test of } \\
\text { Sphericity Chi- } \\
\text { square }\end{array}$ & $\begin{array}{l}\text { Bartlett's Test of } \\
\text { Sphericity Sig. }\end{array}$ \\
\hline Leadership Behavior & 8 & 0.921 & 975 & 0.000 \\
\hline Organizational Innovation & 10 & 0.852 & 729 & 0.000 \\
\hline Managerial Practices & 7 & 0.879 & 744 & 0.000 \\
\hline Business Growth & 5 & 0.859 & 533 & 0.000 \\
\hline
\end{tabular}




\section{Eigen values}

Eigenvalue are those values which are considered to be the principal component that are more than 1 and they apply for the next analysis. Table- 4 indicates all the eigenvalues for explained variance for different constructs. One principal component value was extracted from the given four constructs by using PCA extraction method: Leadership behavior (consisted of eight items explaining $56.36 \%$ variance), Organizational innovation (consisted of ten items explaining $35.56 \%$ variance), Managerial practices (consisted of seven items explaining $56.79 \%$ variance) and Business growth (consisted of five items explaining 63.98\% variance).

Table: 4 EIGEN VALUES

\begin{tabular}{|c|c|c|c|c|}
\hline & \multicolumn{4}{|c|}{ Initial eigenvalues } \\
\hline Construct & Components & Total & $\begin{array}{l}\% \text { of variance } \\
\text { explained }\end{array}$ & $\begin{array}{l}\text { Cumulative \% } \\
\text { of variance } \\
\text { explained }\end{array}$ \\
\hline Leadership Behavior & Comp 1 & 4.509 & 56.362 & 56.362 \\
\hline Organizational Innovation & Comp 1 & 4.268 & 35.563 & 35.563 \\
\hline Managerial Practices & Comp 1 & 3.975 & 56.793 & 56.793 \\
\hline Business Growth & Comp 1 & 3.199 & 63.985 & 63.985 \\
\hline
\end{tabular}

\section{Regression Analysis}

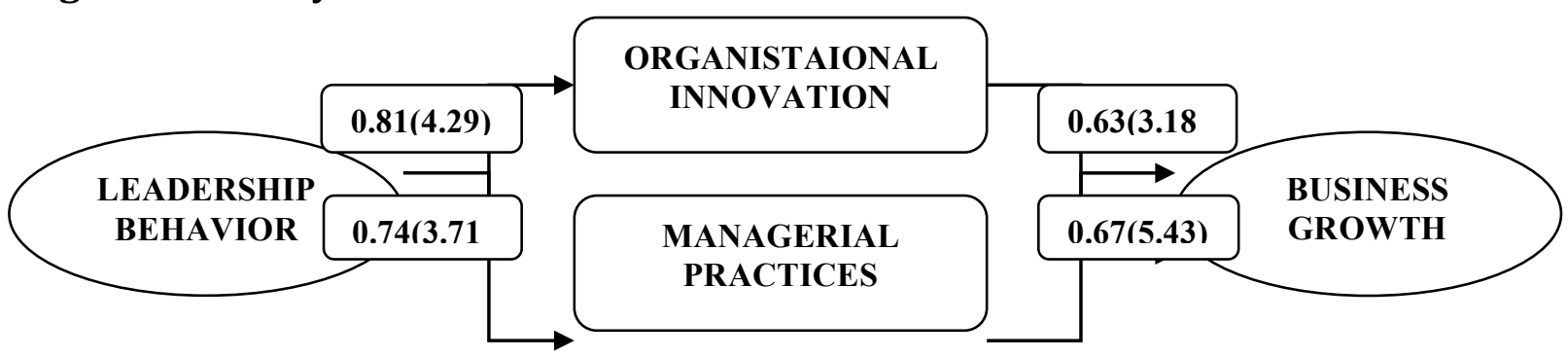

Multiple regression analysis

\begin{tabular}{|l|l|l|l|}
\hline Independent variables & Dependent variable ; Business Growth \\
\hline Leadership Behavior & $0.74(3.74)$ & & \\
\hline Organizational Innovation & & $0.65(4.42)$ & \\
\hline Managerial Practices & & & $0.64(6.58)$ \\
\hline Adjusted R & 0.763 & 0.815 & 0.794 \\
\hline f-statistics & 0.739 & 0.782 & 0.671 \\
\hline
\end{tabular}

\section{CONCLUSION AND MANAGERIAL IMPLICATIONS}

This study emphasizes on organizational innovation and managerial practices in the textile firms through the leadership behavior that enhances business growth. Effective organizational learning generates the technological environment that has leadership to enable innovation and maintain the competitive positions in textile sector (Senge, 1994). Transformational leadership encourages the combination of fundamental beliefs, expectations and principles. These believe and expectations enhance the rules of behavior with the conduct of individuals and groups. Research shows that leadership behavior has different effects on the organizational innovation and managerial performances that depending on the level of organizational learning in the textile firms. It is verified through this research that leadership behavior and encourages organizational innovation and managerial practices which focuses on the business growth that minimizes the cost of internal change. 
This study supports the impact of encouraging the leadership in generating firm's innovation. This study also claims that the characterization of leadership behavior are more concern with the group decisions, collective organizational goals and generating capabilities. Finally, textile producing organizations need for the productive innovation to improve their working performance in the real-life business environment. It is asserted that effective innovation generates better business performances in the productive firms and this relationship is more intense as, the managerial learning and performances increases. The empirical results depict that the sources of business innovation, achieving sustainable competitive advantages and sustainable development in the textile firms are sustainable by the presence of an essential competencies that organizations possess. In this way, firms acquire a dynamic and innovative vision that enable them to improve business performances, generating resources and technological capabilities that are unique and difficult to imitate.

This model analyses the different effects of leadership behavior on innovation, managerial practices and business growth which depending on level of organizational performances. It is also examined that other consequences of introducing an organizational innovation process in textile organizations. More, attention to the effect of specific technological strategic elements on innovation is necessary in future. Future studies should rely on the large sample and should explicitly integrate the effects of external factors. It would also be interesting to study more for similar characteristics with more information provided by the lower levels of the firm's management and members working in it.

\section{References}

Adair, J. (1990). The challenge of innovation.The Talbot Adair Press.

Adler, R.S., \& Borys, B. (1996). Two Types of Bureaucracy: Enabling and Coercive.Administrative Science Quarterly,41(1), 61-89.

Argyris, C., \&Schon, D.A. (1996). Organizational learning II: theory, method, and practice. London:Addison-Wesley.

Bass, B.M. (1991). From transactional to transformational leadership: learning to share the Vision.Organizational Dynamics, 19(3), 19-31.

Bass, B.M. (1999). Two decades of research and development in transformational leadership. European Journal of Work and Organizational Psychology,8(1), 9-32.

Bass, B.M., \& Avolio, B.J. (2000). MLQ multifactor leadership questionnaire technical report. Thousand Oaks: Sage Publications.

Baets, W.R.(1998). Organizational Learning and Knowledge Technologies in a Dynamic Environment. Kluwer Academic Publishers, Boston.

Bellivean, P., Griffin, A., \&Somermeyer, S.(2002). The PDMA tool book for new product development. New York: John Wiley \& Sons, Inc.

Bierly, P.E., Kessler, E.H. and Christensen, E.W. (2000). Organizational learning, knowledge and wisdom.Journal of Organizational Change Management, 13(6), 595-618.

Bookhart, S.W.(1996). Reengineering or benchmarking? It's time to blend the two. Quality Management Forum, 22 (Spring), 10-11.

Bukowitz, W. \& Petrash, G.(1997). Visualizing, measuring and managing knowledge. Research Technology Management,40, 24-31.

Calantone, R.J., Di Benedetto, A.C.,\& Schmidt, J.B.(1999). Using the analytic hierarchy process in new product screening. Journal of Product Innovation Management, 16, 65-76.

Calantone, R.J., Cavusgil, T.S. \& Zhao, Y. (2002), "Learning orientation, firm innovation capability, and firm performance".Industrial Marketing Management, 31, 515-524.

Coad, A.F., \&Berry, A.J. (1998). Transformational leadership and learning orientation. Leadership and Organization Development Journal, 19(3), 164-172.

Colbert, A.E., Kristof-Broiatn, A.L., Bradley, B.H.,\& Barrick, M.R.(2008). CEO transformational leadership: the role of goal importance congruence in top management teams. Academy of Management Journal, 51(1), 81-96. 
Rafiq, M., Haris, M., Anwar, M. J., \& Majeed, K. B. (2017). The Impact Of Leadership Behavior On The Business Growth Through The Organizational Innovation And Managerial Practices. Archives of Business Research, 5(3), 142-155

Collins, R., \&McLaughlin, Y. (1998). Effective Management. Sydney, Australia.

Cooper, R.G.(1999). From experience: the invisible success factors in product innovation. Journal of Product Innovation Management, 16, 115-133.

Cooper, R.G., \&Kleinschmidt, E.L.(1996). Winning businesses in product development: the critical success factors. Research Technology Management,(July-August), 18-29.

Cumming, B.(1999). Understanding Innovation from Cradle to Grave. Butterworth-Heinemann, Oxford.

De Brentani, U.(2001). Innovative versus incremental new business services: different keys for achieving success.

Journal of Product Innovation Management, 18(3), 169-187.

Damanpour, F. (1991) Organizational innovation: a meta-analysis of effects of determinants and moderators. Academy of Management Journal, 34, 555-590.

Davenport, T.H. \& Prusak, L.(1998). Working Knowledge: How Organizations Manage What They Know. Harvard Business Press, Boston.

Elkins, T., and Keller, R.T. (2003). Leadership in Research and Development Organizations: A Literature Review and Conceptual Framework. Leadership Quarterly,14, 587-606.

Englund, R.L., \& Graham, R.J.(1999). From experience: linking projects to strategy. Journal of Product Innovation Management, 16, 52-64.

Finkelstein, S., \&Hambrick, D.C. (1996). Strategic Leadership: Top Executives and their Effects on Organizations.

Garcia Morales, V.J., Matías Reche, F., \&Hurtado Torres, N. (2008b). Influence of transformational leadership on organizational innovation and performance depending on the level of organizational learning in the pharmaceutical sector. Journal of Organizational Change Management, 21(2), 188-212.

Garcia Morales, V.J., Lloréns Montes, F.J.,\& Verdú Jover, A.J. (2008). The effects of transformationalleadership on organizational performance through knowledge and innovation. British Journal of Management, 19(4), $299-319$.

Golhar, D. Y., \& Deshpande, S.P.(1997). HRM Practices of Large and Small Canadian Manufacturing Firms.Journal of Small Business Management,35(3), 30-38.

Gowen, C.R., Henagan, S.C.,\& McFadden, K.L. (2009). Knowledge management as a mediator for the efficacy of transformational leadership and quality management initiatives in US health care. Health Care Management Review, 34(2), 129-40.

Gumusluoglu, L.,\& İlsev, A. (2009). Transformational leadership, creativity, and organizational innovation. Journal of Business Research, 62(4), 461-473.

Hornsby, J. S., \&Kuratko, D.K. (1990). Human Resource Management in Small Firms: Critical Issues for the 1990.Journal of Small Business Management,28(July), 9-18.

Hudges,M. \& Morgan, R.R. (2007). Deconstructing the relationship between entrepreneurial orientation and business performance at the embryonic stage of firm growth. Industrial Marketing Management, 36, 651-61.

Hurley, R.F.,\& Hult, G.T. (1998). Innovation, market orientation, and organizational learning: an integration and empirical examination. Journal of Marketing, 62, 42-54.

Inkpen, A.C., \&Crossan, M.M. (1995). Believing is seeing: joint ventures and organizational learning. Journal of Management Studies, 32, 595-618.

Ireland, R.D., \& Hitt, M.A. (1999). Achieving and maintaining strategic competitiveness in the 21st century: the role of strategic leadership. Academy of ManagementExecutive, 13(1), 43-57.

Irwin, J.G., Hoffman, J.J,\& Lamont, B.T. (1998). The effect of the acquisition of technological innovations on organizational performance: a resource-based view. Journal of Engineering and Technology Management, 15, 2554.

Jones, T.(1997). New Product Development: An introduction to a Multifunctional Process. Butterworth Heinemann. Jones, P. \& Jordan, J.(1998). Knowledge orientations and team effectiveness. International Journal of Technology Management, 16, 152-161.

Kanter, R.M. (1983). The Change Masters, Simon \& Schuster, New York, NY.

Kayworth, T. \&Leindner, D.(2000). The global virtual manager: a prescription for success. European Management Journal, 18, 183-194. 
Kotey, B. (1999). Human Resource Management Practices of Sunshine Coast Small Firms with Reference to the Prescribed Models.International Journal of Employment Studies,7(1), 79-104.

Lian Shao, S.W. (2006). Across-cultural test of the 'five-factor model of personality and transformational leadership'. Journal of Business Research, 59(8), 936-944.

Liberatone, M.J. \&Stylianox, A.C.(1995). Expert support systems for new product development decision making: a modeling framework and applications. Management Science, 41, 1296-1316.

Lengnick-Hall, CA. (1992). Innovation and competitive advantage: what we know and what we need to learn. Journal of Management, 18, 399-429.

Leonard Barton, D. \& Sensiper, S.(1998). The role of tacit knowledge in group innovation. California Management Review,40(3).

McDonough, E.F. (2000), Investigation on factors contributing to the success of cross-functional teams.Journal of Product Innovation Management, 17, 221-235.

MacMahon, J., \&Murphy, E. (1999). Managerial Effectiveness in Small Enterprises: Implications for HRD.Journal of European Industrial Training,23(1), 25-35.

Maltz, E.(2000). Is all communication created equal? An investigation into the effects of communication mode on perceived information quality. Journal of Product Innovation Management, 17(2), 110-127.

Manz, C., Barstein, D.T., Hostager, T.J. \& Shapiro, G.L. (1989), "Leadership and innovation: a longitudinal process view", in van de Ven, A., Angle, H.L. and Poole, M.S. (Eds), Research on the Management of Innovation.The Minnesota Studies.

Mendelson, H. \& Pillai, R.R.(1999). Information age organizations, dynamics and performance. Journal of Economic Behavior and Organization, 38(3), 253-281.

Menguc, B., Auh, S.,\& Shih E. (2007). Transformational leadership and market orientation: implications for the implementation of competitive strategies and business unit performance. Journal of Business Research, 60(4), 314-21.

Mumford, M.D., Scott, G.M., Gaddis, B., Strange, J.M. (2002). Leading Creative People: Orchestrating Expertise and Relationships. Leadership Quarterly,13(6), 705-750.

Nadler, D.A., \& Tushman, M.L. (1990). Beyond the charismatic leader: leadership and organizational change.California Management Review, 32(2), 77-97.

Nonaka, I.,\& Takeuchi, H. (1995). The knowledge-creating company: how Japanese companies create the dynamics of innovation.Oxford University Press.

Ogbonna, E., \&Harris, L.C. (2000). Leadership style, organizational culture and performance: empirical evidence from UK companies. International Journal of Human Resource Management, 11(4), 766-88.

Poulton, J. \& Barclay, I.(1998). New product development from past research to future applications. Industrial Marketing Management,27(3), 197-212.

Rafiq, M., Ilyas, M., \& Rehman, C. A. (2015). Linkage Between Entrepreneurial Education and Intention and desire for venture creation. Pakistan Business Review, 17(2), 366-364.

Rodriguez Ponce, E.(2007). Leadership styles, strategic decision making and performance: an empirical study in small and medium-size firms. Interciencia, 32(8), 522-8.

Rowden, R.W. (2002). High Performance and Human Resource Characteristics of Successful Small Manufacturing and Processing Companies.Leadership and Organizational Development Journal,23(2), 79-83.

Ruggles, R.(1998). The state of the notion: knowledge management in practice. California Management Review, 40, 8089.

Slater, S.F.,\& Narver, J.C. (1995). Market orientation and the learning organization. Journal of Marketing,59(3), 6374.

Schein, E.H. (1993). On dialogue, culture, and organizational learning. Organizational Dynamics, 22(2), 40-51.

Senge, P.M. (1990). The fifth discipline. New York: Doubleday Publication.

Senge, P.M., Roberts, C., Ross, R.B., Smith, B.J. and Kleiner, A. (1994). The Fifth Discipline Field book, Doubleday, New York, NY.

Sosik, J.J., Kahai, S.S., \& Avolio, B.J. (1998). Transformational Leadership and Dimensions of Creativity: Motivating Idea Generation in Computer-Mediated Groups. Creativity Research Journal,11(2), 111-121. 
Shepherd, C.,\& Ahmed, P.K.(2000). From product innovation to solutions innovation: a new paradigm for competitive advantage. European Journal of Innovation Management, 3, 100-106.

Tushman, M.L., \&Nadler, D.A. (1986). Organizing for innovation. California Management Review,28(3), 74-92.

Van de Ven, A.H. (1993). "Managing the process of organizational innovation”, in Huber, G.P. and Glick, W.H (Eds), Organizational Change and Redesign: Ideas and Insights for Improving Performance.Oxford University Press, New York, NY, pp. 269-94.

Wick, C.W.,\& Leon, L.S. (1995). From ideas to action: creating a learning organization. Human Resource Management, 34, 299-311.

Wilkinson, A. (1999). Employment Relations in SMEs.Employee Relations,21(3), 206-217.

Zahra, S.A. \& George, G. (2002). Absorptive capacity: a review, reconceptualization, and extension.Academy of Management Review, 27(2), 185-203.

Zhu, W.C., Chew, K.H., \& Spangler, W.D. (2005). CEO transformational leadership and organizational outcomes: the mediating role of human-capital-enhancing human resourcemanagement. Leadership Quarterly, 16(1), 39-52.

Zollo, M.,\& Winter, S.G.(2002). Deliberate learning and the evolution of dynamic capabilities. Organization Science, $13,339-351$. 